УДК 656.615.003

DOI: https://doi.org/10.32851/2708-0366/2021.10.7

Лисий Є.O.

здобувач третього освітнього рівня, Донецький державний університет управління

Lysyi Eugene

Donetsk State University of Management

\title{
ШЛЯХИ ПІДВИЩЕННЯ РЕЗУЛЬТАТИВНОСТІ ТА ЕФЕКТИВНОСТІ ПРОЦЕСУ УПРАВЛІННЯ ПІДПРИЄМСТВАМИ МОРСЬКОЇ ТА РІЧКОВОЇ ГАЛУЗІ
}

\section{WAYS TO IMPROVE THE EFFICIENCY AND EFFICIENCY OF THE MARKET AND RIVER INDUSTRY MANAGEMENT PROCESS}

У статті розглянуто иляхи підвищення результативності та ефективності процесу управління підприємствами морської та річкової галузі. Визначено, щзо розрахунок показників результативності та ефективності - необхідна умова побудови повноцінної системи управління, тому щзо иі категорї̈ є невід'ємними характеристиками управлінського прочесу. При иььому їх часто визначають як відночення значень отриманих результатів до вироблених витрат. 3 аналізу наукової проблеми визначення сутності понять "результативність» та «ефективність» можна визначити, цчо ијі поняття не мають однозначного тлумачення. Порівнюючи думки визнаних вітчизняних $i$ зарубіжних учених, необхідно відзначити, щзо здебільшого поняття "результативність» $i$ "ефективність» розглядаються як взаємодоповнюючі категорії, причому якщцо результативність - уміння вибрати основну мету, то ефективність - уміння правильно використовувати ресурси для досягнення мети. Основна теза статті: результативність управління підприємств морської та річкового галузі-це виконання виробничих функцій, а ефективність управління - це досягнення економічного та соиіального ефекту.

Ключові слова: результативність, ефективність, процес управління, підприємства морської та річкової галузі.

В статье рассмотрены пути повышения результативности и эффективности проиесса управления предприятиями морской и речной отрасли. Определено, что расчет показателей результативности и эффективности - необходимое условие построения полноценной системы управления, потому что эти категории являются неотъемлемыми характеристиками управленческого прочесса. При этом их часто определяют как отношение значений полученных результатов к производимыл затратам. На основании анализа научной проблемь определена сущность понятий «результативность» и «эффективность», при этом можно отметить, что эти понятия не имеют однозначного определения. Отмечено, что в большинстве случаев понятия «результативность» и «эффективность» рассматриваются как взаимодополняющие категории, причем если результативность - умение выбрать основную иель, то эффективность - умение правильно использовать ресурсы для достижения цели. Основной тезис статьи: результативность управления предприятий морской и речной отрасли - это выполнение производственных функций, а эффективность управления - это достижение экономического и сочиального эффекта.

Ключевые слова: результативность, эффективность, процесс управления, предприятия морской и речной отрасли.

The article discusses ways to improve the efficiency and effectiveness of the process of managing enterprises in the marine and river industry. It has been determined that the calculation of performance and efficiency indicators is a necessary condition for building a full-fledged management system, because these categories are integral characteristics of the management process. Moreover, they are often defined as the ratio of the values of the results obtained to the costs incurred. Based on the analysis of the scientific problem, the essence of the concepts of efficiency and effectiveness is determined, while it can be noted that these concepts do not have an unambiguous definition. It is noted that in most cases "efficiency" and "efficiency" are 
considered as complementary categories, and if efficiency is the ability to choose the main goal, then efficiency is the ability to use resources correctly to achieve the goal. The main thesis of the article: the effectiveness of management of enterprises of the marine and river industry is the performance of production functions, and the effectiveness of management is the achievement of economic and social effect.

Key words: efficiency, efficiency, management process of the enterprise of the marine and river industry.

Постановка проблеми. Визначення результативності та ефективності управління - це завершальна стадія управлінського процесу. «Ефективність - це робити речі правильно; результативність - це робити правильні речі», - казав Пітер Друкер.

Ефективність, згідно з ISO 9000:2000, - це співвідношення досягнутих результатів i використаних ресурсів. Фактично ідентичне визначення дає Сучасний економічний словник: «Ефективність - відносний ефект, результативність процесу, операції, проєкту, що визначаються як відношення ефекту, результату до витрат, що забезпечили його отримання» [1]. Таким чином, щоб вимірювати результативність, потрібно мати чітко визначені цілі і плани. Без цього у нас не буде точки відліку для оцінки результативності. Для вимірювання ефективності будь-якого процесу потрібно вміти визначати витрати на виконання цього процесу. Якщо це вдається зробити, то керівництво підприємства завжди може визначити, чи були досягнути цілі та які ресурси для цього були витрачені.

Розрахунок показників результативності та ефективності - необхідна умова побудови повноцінної системи управління, тому що ці категорії $є$ невід'ємними характеристиками управлінського процесу. При цьому їх часто визначають як відношення значень отриманих результатів до вироблених витрат.

Аналіз останніх досліджень і публікацій. Дослідження процесу управління пов'язані з іменами Ф.У. Тейлора, Френка та Лілії Гілбрет, Г. Гантта. Важливим досягненням цих учених було дослідження управління за допомогою наукового підходу, який вони будували, спираючись на економічний, технічний та соціальний експерименти.

Серед сучасних авторів, що займаються визначенням сутності категорії «ефективність», вивченням теоретичних основ і принципів управління, слід виділити Ф. Аналоуі, Дж.Л. Гібсон, Д. Донеллі, П. Друкера, Д. Іванцевіч, Р. Каплана, М. Мейєра, Д. Нортона та ін.

Р. Каплан та Д. Нортон розробили збалансовану систему показників ефективності організації, що забезпечила новий підхід до стратегічного управління компаніями будь-якої складності, що оперують у різних галузях діяльності. Дана система заснована на причинно-наслідкових зв'язках між стратегічними цілями, що відображають їхні параметри та фактори отримання планованих результатів. На відсутність загального розуміння категорії «ефективність» як у теоретичному, так і практичному сенсі вказували Нобелівські лауреати та інші світові дослідники та вчені [2].

Ці категорії $є$ предметом наукових досліджень і вітчизняних учених. Так, у статті [3] автори на основі поглибленого аналізу зазначених понять у висловлюваннях вітчизняних та закордонних науковців дійшли висновку, що ці категорії не є синонімами, але $€$ взаємопов'язаними: «Термін «ефект» має значення результату, отриманого внаслідок зміни стану певного об'єкта, зумовленого дією зовнішнього або внутрішнього фактора. Категорію «ефективність» слід розуміти як співвідношення отриманого результату до витрат на досягнення даного ефекту (результату)».

Автор статті [4] наголошує на тому, що управління ефективністю - це процес, а ефективність та результативність - це кінцеві продукти цього процесу, що мають різні показники оцінювання.

Формулювання цілей статті. На основі теоретичних досліджень закордонних та вітчизняних учених запропоновувати шляхи підвищення результативності та ефективності процесу управління підприємствами морської та річкової галузі. 
Виклад основного матеріалу. Ефективність управління - це відношення отриманого результату (прибутку) до витрачених ресурсів (інвестицій).

Під час розгляду сутності та змісту ефективності необхідно виходити із загального і приватного розуміння ефективності людської діяльності. «Ефективність» означає здатність приносити результат і походить від слова «ефект» (від лат. effectus - дія) [5].

Таким чином, ефектом може володіти будь-яка взаємодія, що має якийсь результат. У цьому сенсі ефект можна розглядати як абсолютну властивість будь-якої взаємодії або процесу, що характеризує їх результат. На думку Ю.С. Гупанової, у найбільш простому формулюванні поняття ефективність - це здатність приносити ефект, чинити дію [6].

У цих умовах, як зазначає С.Н. Растворцева, оцінка ефективності повинна передбачати зміни показників ефективності в динаміці і по відношенню до плану [7]. У цьому контексті визначається ступінь відхилення від показника порівняння, виявляються проблеми підвищення ефективності за окремими напрямами, що дає змогу скласти ієрархію проблем та виявити резерви підвищення результативності.

3 аналізу наукової проблеми визначення сутності понять «результативність» та «ефективність» можна зазначити, що ці поняття не мають однозначного визначення. Порівнюючи думки визнаних вітчизняних і зарубіжних учених, доходимо висновку, що здебільшого поняття «результативність» і «ефективність» розглядаються як взаємодоповнюючі категорії, причому якщо результативність - уміння вибрати основну мету, то ефективність - уміння правильно використовувати ресурси для досягнення мети.

Отже, як бачимо, існує багато підходів до визначення поняття «ефективність». Одні автори та науковці пов'язують ефективність з ефектом, інші розглядають ії як співвідношення результату та витрат. При цьому ефект розглядається як певна форма результату. Але більшість науковців ототожнює поняття «ефективність» і «результативність». На нашу думку, це не зовсім правильно, оскільки результативність - це досягнення певного результату, який не обов'язково повинен бути позитивним. А ефективність - це завжди позитивна величина, що характеризує приріст результатів у співвідношенні із засобами їх досягнення.

Розмежування понять «результативність» та «ефективність» було затверджено і в ДСТУ ISO 9000:2007, де результативність (effectiveness) визначається як ступінь реалізації запланованої діяльності та досягнення запланованих результатів, а ефективність (efficiency) - це співвідношення між досягнутим результатом і використаними ресурсами.

Для забезпечення результативності ключове значення має певна низка факторів (КФ), що відображаються у певних ключових показниках (КП), які повинні регулярно оцінюватися. Високий рівень результативності відображає високий рівень задоволення потреб та очікувань зацікавлених осіб підприємства, що, своєю чергою, у поєднанні з відповідними показниками ефективності забезпечують досягнення стабільного успіху підприємства [9].

Можна також виділити певні відмінності між показниками результативності та ефективності. Обидва показники є якісними. Але якщо певний показник ефективності розглядається як ключовий показник діяльності підприємства, то він може вважатися кількісним. Результативність оцінює результат із погляду співставлення його із запланованими, а ефективність - із витраченими ресурсами. Відповідно, показник результативності спрямований на збільшення, поліпшення результату, а показник ефективності - на зменшення витрат [9].

Таким чином, можна дійти висновку, що функція досягнення мети має велике значення під час визначення ефективності. Підхід до розгляду ефективності з позиції досягнення мети не суперечить підходу до розгляду ефективності у значенні результативності, він має більш складний характер, критеріями цього підходу є відповідність фактичного результату поставленій меті. Ефективність, розглянута 3 позиції досягнення мети, характеризує якість отриманого результату. 
Ефективність як міра отриманих підприємством результатів, віднесених до витрачених для їх отримання ресурсів, застосовується для різноманітних аналітичних оцінок та обгрунтування господарських рішень, тому можуть бути виділені окремі види ефективності для певних практичних потреб діяльності підприємства.

У науковій літературі існує понад 20 класифікацій ефективності. Найбільш поширеною є класифікація, згідно з якою ефективність виступає у трьох видах: економічна, соціальна, соціально-економічна. Ця класифікація ефективності є основою всіх інших поділів і тому є загальною.

У науковій літературі пропонують використовувати декілька методичних підходів оцінки ефективності:

- традиційний підхід. Базується на класичній моделі Дюпона «Рентабельність капіталу», передбачає оцінку ефективності на основі двох груп показників: узагальнюючих - показників першого рівня, які характеризують ефективність діяльності підприємства у цілому, та показників другого рівня, які оцінюють ефективність використання окремих видів ресурсів підприємства;

- багаточинниковий підхід. Передбачає використання агрегованих індексів ефективності, що є складними і важкими для інтерпретації, а тому і не став загальновизнаним;

- оцінка ефективності діяльності на основі концепції Performance Management (управління результативністю) передбачає використання так званої збалансованої системи індикаторів (Balancea Scorecard (BSC)), яка включає різні фінансові й нефінансові показники, що дають змогу комплексно оцінити вартість підприємства й ефективність його діяльності. Показники рентабельності використовуються у цій системі як другорядні, а основним є економічна додана вартість (EVA) [9].

Підприємства морської та річкової галузі - це підприємства, які здійснюють діяльність у галузі морського і річкового транспорту та належать до сфери управління Міністерства інфраструктури України.

До таких підприємств відноситься «Адміністрація морських портів України» одне 3 найбільших державних підприємств, що має стратегічне значення для економіки та безпеки України. Було створено у 2013 р. в результаті реформи морської галузі України для управління державним майном у морських портах країни та ії ефективного використання, створення механізмів для залучення інвестицій у портову інфраструктуру для її розвитку та стабільної роботи бізнесу [10].

Серед інших завдань Адміністрації - підтримання паспортних глибин акваторій портів, забезпечення безпеки мореплавання та ін. АМПУ входить до сфери управління Міністерства інфраструктури України та поєднує українські морські порти та інші інфраструктурні елементи, сприяючи розвитку та конкурентоспроможності кожного 3 них. Структура підприємства складається із центрального офісу в Києві та головного представництва в Одесі, філій «Дельта-Лоцман» та «Днопоглиблювального флоту», а також 13 філій у морських портах України.

Також до таких підприємств належать ПрАТ «Судноплавна компанія «Укррічфлот»; державне підприємство «Чорноморське морське пароплавство», орендне підприємство «Азовське морське пароплавство», ПрАТ «Українське Дунайське пароплавство», ТОВ «Судноплавна компанія «Укрферрі»; Одеське морське пароплавство; Південне річкове пароплавство; Українське морське пароплавство; Чорноморське муніципальне пароплавство; «Нібулон»; Argo Shipping Group та ін.

Результативність управління підприємствами морської та річкового галузі - це виконання виробничих функцій, а ефективність управління - це досягнення економічного та соціального ефектів.

У цьому досліджені приділено увагу шляхам підвищення ефективності через конкурентоспроможність саме морських портів України. Для цього застосовано процесний, маркетинговий та кластерний підходи, які диференціюються залежно від 
специфіки функціонування самого морського порту. Так, процесний підхід передбачає неперервний взаємозв'язок дій та функцій, спрямованих на підвищення рівня конкурентоспроможності порту, ураховуючи технологію надання портових послуг, види виробничо-економічних ресурсів, особливості стратегічного та маркетингового менеджменту. Це один із найбільш поширених та традиційних підходів.

Маркетинговий підхід передбачає визначення вузької спеціалізації портових послуг, реалізацію дій, спрямованих на досягнення їх високої якості, формування клієнтської бази, оптимізацію трансакційних витрат, ураховуючи логістичні ланцюжки морського порту. Тобто застосування даного підходу як основи забезпечення конкурентоспроможності перш за все зорієнтовано на чинники зовнішнього середовища та внутрішнього макросередовища. При цьому якість послуг та клієнтоорієнтованість $€$ ключовими орієнтирами діяльності. Перехід від процесного та маркетингового підходів зумовлений постійним зростанням конкуренції у сфері портових послуг та високоінтенсивною динамікою чинників ринкової кон'юнктури. Найбільш ефективним сьогодні є кластерний підхід, який передбачає створення структури (портово-логістичного кластеру), у якій усі учасники набувають додаткові конкурентні переваги за допомогою сукупного впливу ефектів масштабу і синергії.

Таким чином, створюються умови для розвитку інтеграційних зв'язків між морським портом, промисловими, транспортними та іншими підприємствами території, структурами влади, консалтинговими підприємствами і транспортно-логістичними системами та, як наслідок, забезпечується формування промислово-портового кластера.

Висновки. Визначені підходи до забезпечення конкурентоспроможності слід розглядати як методологічну основу забезпечення конкурентоспроможності морського порту, ураховуючи роль порту в економіці країни чи регіону як елемента інфраструктури і логістичної системи, особливості сучасного розвитку, що проявляються в глобалізації економіки та інтеграції бізнесу.

На нашу думку, зазначені підходи забезпечать підвищення конкурентоспроможності порту, у рамках яких запропоновано виділяти принципи, форми, методи та інструменти, що зумовлюють характер дій, спрямованих на досягнення цілей, створення сприятливих умов для ефективного використання ресурсів порту та вигідного позиціонування порту в конкурентному середовищі регіону, що сприятиме результативності та підвищенню ефективності управління портом.

\section{Список використаних джерел:}

1. Райзберг Б.А., Лозовский Л.Ш., Стародубцева Е.Б. Современный экономический словарь ; 2-е изд., испр. Москва : ИНФРА-М, 1999. 479 с.

2. Каплан Р., Нортон Д. Сбалансированная система показателей. От стратегии к действию / пер. с англ. ; 2-е изд., испр. и доп. Москва : Олимп-Бизнес, 2004. 320 с.

3. Кравченко О.А., Ільницький В.В., Ульяновський О.І. Забезпечення результативності і ефективності виробничої діяльності підприємства. Економіка: реалї часу. 2013. № 3(8). С. 29-35. URL: http://economics.opu.ua/files/archive/2013/n3.html

4. Насонов М.I. Методика оцінювання управління ефективністю підприємства: теоретичні аспекти. Ефективна економіка. 2018. № 11. URL: http://www.economy.nayka.com.ua/ ?op=1\&z=6711 DOI: 10.32702/2307-2105-2018.11.204 (дата звернення: 21.09.2021).

5. Экономический словарь / под ред. А.Н. Азрилияна. Москва : Институт новой экономики, 2007. $1120 \mathrm{c}$.

6. Гупанова Ю.Е. Методологические и методические основы управления качеством таможенных услуг в условиях неопределенности и риска : монография. Москва : PTA, 2012. 164 с.

7. Растворцева C.Н. Эффективность в системе управления. URL: http://www.rusnauka.com/ TIP/All/ Economica/110.html

8. Рябкова О.В. Сутність результативності та ефективності діяльності підприємства. URL: http://mev-hnu.com/load/2013/7_konkurentnij_potencial_pidpriemstva_metodi_ta_mekhanizmi_ pidvishhennja/37-1-0-246 
9. Кусик Н.Л., Ковалевська А.В. Проблема визначення ефективності. Методичні підходи до оцінки ефективності діяльності підприємства. Проблеми економіки. 2012. № 3. URL: http://pidruchniki.com/1854051647541/ekonomika/problema_viznachennya_efektivnosti_ metodichni_pidhodi_otsinki_efektivnosti_diyalnosti_pidpriyemstva

10. Адміністрація морських портів України. URL: http://uspa.gov.ua/index.php?lang=ua

\section{References:}

1. Rajzberh B.A., Lozovskyj L.Sh., Starodubtseva E.B. (1999) Sovremennyj ekonomycheskyj slovar. Moscow: YNFRA-M, $479 \mathrm{p}$.

2. Kaplan R. (2004) Sbalansyrovannaia systema pokazatelej. Ot stratehy k dejstvyiu. Moscow: Olymp-Byznes, $320 \mathrm{p}$.

3. Kravchenko O.A., Il'nyts'kyj V.V., Ul'ianovs'kyj O.I. (2013) Zabezpechennia rezul'tatyvnosti i efektyvnosti vyrobnychoi diial'nosti pidpryiemstva. Ekonomika: realii chasu. Naukovyj zhurnal, no. 3(8), pp. 29-35. Available at: http://etsonomitss.opu.ua/files/archive/2013/n3.html

4. Nasonov M. I. (2018) Metodyka otsiniuvannia upravlinnia efektyvnistiu pidpryiemstva: teoretychni aspekty. Efektyvna ekonomika, no. 11. Available at: http://www.economy.nayka.com.ua/ ?op=1\&z=6711 DOI: 10.32702/2307-2105-2018.11.204 (accessed 21 September 2021).

5. Ekonomycheskyj slovar' (2007) / Pod red. A.N. Azrylyiana. Moscow: Ynstytut novoj ekonomyky, p. 1120.

6. Hupanova Yu.E. (2012) Metodolohycheskye y metodycheskye osnovy upravlenyia kachestvom tamozhennykh usluh $\mathrm{v}$ uslovyiakh neopredelennosty y ryska: monohrafyia. Moscow: Yzd-vo RTA, $164 \mathrm{p}$.

7. Rastvortseva S.N. (2010) Effektyvnost' v systeme upravlenyia. Available at: http://vvv.rusnauka.tsom/TIP/All/Etsonomitsa/110.html

8. Riabkova O.V. (2013)Sutnist' rezul'tatyvnosti ta efektyvnosti diial'nosti pidpryiemstva. Available at: http://mev-hnu.tsom/load/2013/7_konkurentnij_potentsial_pidpriemstva_metodi_ta_ mekhanizmi_pidvishhennia/37-1-0-246

9. Kusyk N.L., Kovalevs'ka A.V. (2012) Problema vyznachennia efektyvnosti. Metodychni pidkhody do otsinky efektyvnosti diial'nosti pidpryiemstva. Problemy ekonomiky, no. 3. Available at: http://pidruchniki.tsom/1854051647541/ekonomika/problema_viznachennia_efektivn osti_metodichni_pidhodi_otsinki_efektivnosti_diialnosti_pidpriiemstva

10. Administratsiia mors'kykh portiv Ukrainy (2021). Available at: http://uspa.gov.ua/indekh. php?lang=ua 